\title{
Conceptualization of the Image of Siberia in Contemporary Travel Literature
}

\author{
Liubov P. Bolshakova* \\ North-Eastern Federal University named after M.K. Ammosov \\ 58 Belinsky Str., Yakutsk, 677000, Russia
}

Received 14.12.2015, received in revised form 20.01.2016, accepted 03.03.2016

\begin{abstract}
The article offers a study of conceptualization of Siberia in the English language picture of the world. The objects of study are the means of linguistic representation, which provide conceptualization of the image of the Russian North. The article considers the literary travel writings by contemporary foreign writers-travelers, who took trips to Siberia, which were resulted in fascinating travelogues. The current investigation is undertaken to analyze the conceptualization of the image of the Russian North in the linguistic picture of the world, which results from analyzing the words, their meanings and associations in the mind of a linguistic identity of the English speakers in the process of thinking about the objects and phenomena related to the Russian North. The concepts were identified through revealing the key words by continuous sampling method and set of categories in the result of analysis of the meanings of linguistic units, which represent the "Siberia" concept. Thus, foreign travelers associate the Russian North both with the extreme weather conditions, geographical remoteness, inaccessibility and also with rich, but tragic, violent history, the beauty of the northern nature, sincerity and kindness of the Siberian natives, unusual way of their life and extremely harsh living conditions. The research shows that revealed concepts resulted in the creation of the image of Siberia as a distinguished from every other - as a metaphor for cold and remoteness, embodied in oxymoron of oppression and freedom.
\end{abstract}

Keywords: conceptualization, Siberia, literary image, contemporary travel literature, English language picture of the world.

DOI: 10.17516/1997-1370-2016-9-3-551-558.

Research area: philology.

Despite defined geographic and the term "North" is largely complicated by the administrative borders, Siberia is still a relevant lack of an established definition and vagueness subject of dispute for many scientists. It is of its boundaries. However, there is no doubt considered much broader and deeper than just that the North is a special cultural space, a a geographical concept. However, it is obvious that Siberia is Russian land, i.e. it belongs geographically and is associated with deep territories of the Russian North. Understanding place of formation and development of different indigenous cultures. In our study Siberia is defined as geographically Russian North with its unique flora and fauna, a home of distinctive

(C) Siberian Federal University. All rights reserved

* Corresponding author E-mail address: bolshaklove@yandex.ru 
peoples with their amazingly rich cultural and community traditions.

The concept of the Russian North has still not been fully investigated. It holds a specific place in Russian and foreign sphere of concepts. Being a multi-dimensional notion of cognitive categories, the concept provides a large field for its interpretation. In a logical glossary (Kondakov, 1975: 235) the term "concept" is defined as a general idea, main idea and basic idea of a theory; way of understanding and interpretation of phenomena, events. Philosophical dictionaries determine the "concept" as formulization, mental image, notion (Philosophical Dictionary 1991: 203; Philosophical Dictionary 1963: 214). Encyclopedias give a general definition as "the content of the notion, the meaning" (Soviet Encyclopedic Dictionary 1982: 624) and "the meaning of the name (signs), i.e. the content of the notion, the scope of which is the object (denotation) of the name" (Great Encyclopedic Dictionary, 2008: 456). However, it is obvious that all the sources define the concept as a mental structure semantically fundamental to any idea or phenomenon.

In cognitive linguistics the concept is considered as a mental formation, a system of images and associations emerged in perception and understanding of reality. There are three approaches to defining the term: the concept as a basic unit of culture (Stepanov, Karasik); as a unit of linguistic worldview and a product of national cultural mentality (Arutyunova, Bulygin, Shmelev); as a result of the collision of word meaning with a personal and national human experience, i.e. it is an intermediary between the words and reality (Likhachev, Kubryakova).

The concepts "reduce the variety of observed and imagined phenomena to something uniform, bringing them under one heading" (Kubryakova 1996: 90), thus, it makes sense to assume that the concepts help you to organize everything seen and perceived in a single image. Moreover, on the contrary, the image can be verbalized and find expression in the conjunction of the concepts.

Thematic justification of the article is based in the study of the conceptualization of the image of Siberia in the linguistic consciousness of the English-speaking travelers, exepmlified in their travel writings. Therefore, considering the conceptualization as an individual author's interpretation of reality, we can draw conclusions on english-speaker's attitude and perception of the Russian North. The study materials include literary works of contemporary writers, who traveled to Siberia or resided in its territory a significant period of their life. There is a work by the Canadian writer-naturalist Farley Mowat 'Sibir. My Discovery of Siberia' (1970), where the author describes his journey through Siberia and his life in Yakutia in the Soviet era. Next travel book appears no less important - the work by the British writer-traveler Colin Thubron 'In Siberia' (2000). The writer visited Siberia in the late ' $90 \mathrm{~s}$ after the fall of communism. The author faces with the unearthly beauty of Siberian nature and admires the expanse of the North and rich diversity of natural resources. However, Thubron is depressed by the fact that everywhere he sees the traces of the Gulag and the Soviet Union. Next author is the American writer Ian Frazier, who also narrates about the post-Soviet Siberia in his 'Travels in Siberia' (2010). The writer reveals Siberia in a historical context, he seems more interested in exploring Siberia's past, describing the facts from science, politics, economics and the most famous political exiles. 'Travels in Siberia' is also a diary of the author's adventures through the cities and villages of Siberia. The next work tells the story of a British family in the person of the writer Doreen Stanford, who settled in the far Siberia in pre-revolutionary times. Finally, there is the travelogue by the cyclist Rob Lilwall 'Cycling Home from Siberia' (2009), who took 
an incredible trip between 2004 and 2008, which started in Siberia.

The choice of the contexts for the analysis of the chosen concept is carried out not only by continuous sampling method, but also by the selection of specific formal characteristics, i.e. the contexts that contain the name of the concept, and image-semantic characteristics, which are markers of the author's vision of the world (Zgazinskaya 2008).

Thefirst thing to highlight is the writers' initial impression about the North, which is represented by lexical unit-representant "shock", evolved by frequent repetition of the word and its synonyms: 'fascinated', 'stunned', 'impressed' (Mowat); 'Had a severe shock', 'puzzled', 'everything was exciting to me', 'I was shocked' (Stanford); 'It is shocking' (Thubron); 'I was shocked' (Lilwall). Siberia's 'otherness' is noticed by the travelers from the very first sight that usually results in condition of being overwhelmingly surprised. The frequency of these words in studied travel writings suggests the readers to see the writers' unexpected wonder and meeting with out of the ordinary.

One of the first most frequent and significant phenomena, described in study materials, is the image of Siberia as an inaccessible, unknown world. This leads to the suggestion that the travelers highlight the fact that the North - terra incognita, entering the possession of which the author makes a rare discovery of unknown. It is presented by the lexical units with the central seme «unknown»: 'vast, almost unknown country' (Stanford); 'Even professional northern experts in Canada and the United States seem to have surprisingly little interest in, or knowledge of, the Russian north, misconceptions about Siberia'; 'Yakutsk? Really, nobody goes there '; 'Through the deepest mountain valleys of an unknown world' (Mowat); a vast area of the forbidden world (Thubron); 'No one in the history of civilization has ever bothered to go' (Frazier). Presumably, therefore, the image of the mysterious North is formed: 'huge and, for westerners, mysterious region' (Mowat); 'A mystery' (Stanford); 'It courted hearsay and legend, conjured the ideal, elicited fear; even its name - a mystical conflation ', mystique land '(Thubron); 'Mysterious, scattered luminosity of the Northern Lights' (Lilwall).

The next step is an analysis of formal identifiers of Siberia, containing the name of the concepts Siberia / North, their equivalents and substitutes. Predominately we meet such equivalents as the Arctic; Northern region, the Russian North; Real North (Mowat, Frazier); Far North (Stanford); the Russian Siberia, Russia's North (Thubron). The most frequent word that expresses and qualifies Siberia is possessive determiner 'Russian'. Therefore, the writers use it to indicate that Russia has ownership over Siberia. Some of their equivalents emphasizes, for instance, the administrative territorial belonging of Siberia during the ongoing journey. For instance, Mowat and Thubron name Siberia as Soviet arctic, Soviet North, Stalin's North, as the travelers describe the North in the years of the Soviet Union.

The next type of the analysis context of the studied concept is determined on the basis of the content identifier. In this case, the figurative interpretation of the image of Siberia is performed. The authors-travelers use similes and metaphors associated in the minds of their linguistic identity with Siberia. First of all, the North of Russia is represented as an area with severe climatic conditions. The conceptual dimension of Siberian cold in many descriptions enhanced with additional metaphorical characteristics as bitterly cold; a blast of arctic air; the frozen air; fantastic cold; polar conditions; frozen arctic (Mowat); bitter cold, great cold, icily cold, intense cold (Stanford); static cold, a town [Yakutsk] of ice 
and twilight, frozen air (Thubron); harsh extreme climate (Frazier); icy breath (Lilwall). Thus, there is formation of the specific perception of the Siberian cold: the mere mention of "Siberia" is synonymous with extremely harsh natural conditions in the mind of most of the people. It can be assumed that a well-known expression 'as cold as in Siberia' occurred in a result of this perception.

Taking into account the cognitologists' conclusions that spatial visualization of the world plays a leading role in the formation of linguistic systems, we paid particular attention to the conceptualization of Siberian space in the study materials. As a result, vast geographical distance and spatial unlimitedness are brightly reflected in metaphorical characteristics and images of comparison. In the study materials conceptual dimension of distance and space is represented by means of expression, including lexical units with central semes:

- "unlimitedness": "The map of Siberia can give no real concept of the immensity of that land', 'the taiga alone can give the sensation of illimitable space and distance', 'the most extensive forests in the northern hemisphere', 'limitless expanse of blue-green forest', 'the taiga is a universe without an end', 'an inscrutable and timeless world' (Mowat); 'the huge spaces of Siberia', 'the universal whiteness', 'great stretches of forest' (Stanford); 'the white spaces induce fantasies and apprehension', 'ultimate, unearthly Abroad','everything seems inaccessibly distant', 'elusive and endless' (Thubron); 'Siberia was the blankness, the space', 'Russia's own universe' (Frazier); 'the view rolled away in an otherworldly blend of mountains, streams and forests to an endless horizon', 'the unending plains of Yakutia' (Lilwall);

- "Remoteness / isolation", "location on the edge of the earth", "silence": 'We must have been the strangest visitation to reach this remote place', 'one of the most remote and inaccessible outposts of the Russian Empire', 'the extreme northeastern corner' (Mowat); 'silent solitude', 'in our remote wilderness, we anyway mostly lived off the land and did better than townspeople', 'we were in great distance from home', 'no signs of life' (Stanford); 'emptiness', 'isolated', 'the quiet of this empty space is the quiet of enforced forgetting', 'unearthly silence', 'cathedral peace, 'empty of humans' (Thubron); 'the land simply stretches on and on', 'cold, dark, remote and hibernating' (Frazier); 'I could see no sign of human life', 'still and lifeless' (Lilwall);

- "depth / density": 'the deep taiga', 'the depths of Siberia' (Mowat), 'the frigid blackness', 'dark forests' (Mowat); 'the deep, frightening silence [of the forests]', 'blue dark forest' (Stanford); 'black beauty' (Thubron); 'riding through blackness' (Lilwall).

Consequently, the combination of perception of the North as the infinite, spacious land develops the image of majesty which is expressed in epithets and hyperboles: 'the immense northern forests'; 'the great Siberian rivers', 'this gigantic northern jungle' (Mowat); 'so broad that the far horizon was nearly out of sight' (Stanford); 'too cold and vast to be precisely real' (Thubron); 'eventually you feel you're in the farthest, extra, out-of-sight section', 'gigantically expanded to the horizon-filling width' (Frazier); 'the colossal landmass of far-eastern Siberia' (Lilwall).

Most of the images related to the North of Russia refers to the nature, its objects and phenomena. The authors, first of all, describe pristine and unspoilt natural environment: 'For the first time I smelt the clean fragrance of snowy air', 'It was primeval forest, uncultivated, untouched by man' (Stanford); 'trackless forests' (Mowat); 'Siberia becomes a pole of purity', 'primal Siberia', 'snowbound purity', 'Siberia became the repository of an imagined innocence', 'it was seen as a haven 
of primitive innocence' (Thubron);'the coldest inhabited place in the world', 'so much empty wilderness' (Lilwall). As it can be seen, in the perception of the English linguistic identity Siberian nature is the focus of the purity of the environment.

Thick rich taiga, on the one hand, and the bare steppes, covered with moss and lichen, on the other - such a contrast of the natural environment appears before the eyes of the travelers. This opposition of the zones is brightly described by Mowat: 'muskeg and virtually inpenetrable forests reaching far north of the arctic circle to fade at last into the treeless and frozen tundra of the polar coast'. However, most commonly the authors describe features of the Siberian nature, represented by pale tones/ monotony and poverty of flora: bare, frozen, snow-covered, white wilderness (Mowat); 'the whole world was colourless', 'cold, white world', 'the universal whiteness' (Stanford); 'immense sameness' (Thubron); 'much of Siberia drains poorly and is quite swampy', 'white blankness', 'bare land, empty sea', 'an undramatic kind, like the dull, flat paint jobs', 'open spaces that were gravel and sky and not much else' (Frazier); 'the flat, glaring whiteness of snow', 'black-and-white world'(Lilwall).

Thus, conceptual indication of the Siberian space is widely reflected in the language picture of the world of foreign travelers. Siberia appears to them as inaccessible, rugged, unsuitable for life, but at the same time, pristine, majestic and beautiful place.

Siberia is a place where there are unique peoples with their traditional way of life and beliefs. The image of the northern peoples in many works is presented with the same set of attributes and characteristics. The travelers use different terms for the name of a resident of the North: Arctic native, a Siberian (Mowat), the natives, native Siberian people (Mowat); Indigenous natives, native groups, Arctic peoples, the natives, horse people [Yakut] (Thubron); peoples of Siberia (Frazier). The indigenous peoples of Siberia are mostly presented by Even, Evenk, Yukagir, Yakut, Kets, Dolgans, Entsy, Buryat, Chukchis. Most commonly the travelers give the following features and qualities to the Siberian natives:

- Hospitality: 'warmth of reception' (Mowat); 'we moved to another house, where the owners were again very hospitable' (Stanford); 'they [Yakut] never asked us for money in return for their help and sometimes they even tried to give us money and fur clothing' (Lilwall);

- Sincerity and kindness: 'the emotion was sincere'; 'they became terribly sentimental and full of boundless love for everyone'; 'they radiated the same feeling of passionate sincerity'; (Mowat); 'everyone seems happy' (Thubron); 'welcomed us with big smiles' (Lilwall);

The most significant aspect that unites the northern natives - their smiling faces, cheerful, friendly attitude towards the them. Most often these qualities amaze travelers in the backround of contrast with harsh living in the North. This gratefulness for small favours is incomprehensible to Western man.

- Modesty, simplicity, shyness: shy man; modest (Yakut); Yakut shy girls; a shy young Yukagir (Mowat);

- Staunchness: 'Siberians are tough' (Stanford); 'the Yakut are the iron men' (Thubron);

- Features associated with physical appearance, f.i. to describe the appearance of the northerner, travelers emphasize short stature, dark skin and dark (crow) hair, narrow eyes, wide face: 'a beautiful twenty-year-old with raven hair, glowing olive skin, full red lips and snapping black eyes'; 'broad-faced, darkcomplexioned men'; 'a small man with a winning smil'e; 'a very dark, whipcord-lean little man' 
(Mowat); 'dark people' (Stanford); dark haired, pretty, thin, short, shy, slim, quiet, with round face (Frazier);

- Different beliefs, paganism, polytheism: 'regarded them [buried people] with superstitious veneration', 'to disturb the 'Old People' would bring a curse on everyone for many miles around' (Stanford); 'but most Yakut kept secretly to the old beliefs', 'the shaman was stronger than the priest right to the end of their struggle' (Mowat).

- Changes related to the development of society and living conditions. 'She [Yakut girl] looked, as Claire rather wonderingly remarked, more chic than most college students in Canada' (Mowat); 'They had lost their traditions, people's memory of their nature spirits had dimmed away; nobody any longer knew their oral epics. The places of sacrifice had been left behind in the reindeer tundra (Thubron). Colin Thubron describes the change in Yakut belief: 'from an ancient paganism to a superficial Christianity, then converted to evangelical Communism, then stranded in wilderness', 'to feed the firegod', richness of Sakha's oral epics, polytheism, paganism (Thubron).

In contradiction with the indigenous people of the North there are non-indigenous peoples. Many travelers name them with word-antonyms, words, directly opposed to the nature of an indigenous northerner. For instance, westerner vs northerner; white men; a pale, craggy-faced, intense and very nervous Russian (Mowat); indigenous Siberians and Russian Siberians, the Russians vs the natives (Thubron); Russians and native peoples (Frazier). This supports the formation of regional identity, manifested, in particular, in opposition to "Siberians / Northerners" and "Russia / Russians." Moreover, the authors emphasize the fact that 'aliens' had a certain reasons or purpose for living in the North. For example, doomed political prisoners (Mowat); 'Gulag prisoners' (Thubron). The identifier 'doomed' points to the physical and mental suffering, forced to nonindigenous people.

The conceptualization of the siberian image is also constructed by linguistic units, indicating the culture-specific concepts, i.e. "words for objects, concepts or situations that do not exist in the practical experience of people who speak another language" (Barkhudarov 1975: 95): winter fur boots, fur hats, skin boots; cow-dung cottages; reindeer-skin dwellings, sleds (Frazier, Mowat, Thubron, Stanford). These words represent something specific, unique, that does not exist in "alien" culture. They are, therefore, reflected in the language of the travelers in the form of a set of words that define the subjects, concepts, or situation, unfamiliar to English speaking person. The most striking elements of "different" culture, providing conceptualization of the image of Siberia, are lexical items which do not have equivalents in the language of the travelers - the lacuna: stroganina, yaranga, kayak, borsch, omul, chir, kumiss. Lacunas require a special approach in the text. In the case of the studied travel accounts, all authors identify lacunas in italics.

Siberia is pictured in the travelogues as a vast territory that has no end either vertically or horizontally. Two natural areas, most often mentioned in the works, are rich fertile taiga and bald cold tundra. The writers brightly depict the difference in their flora and fauna, describing the tundra a bare, cold, poor location and taiga as a rich, blue-black forest, home to the majority of birds and animals throughout Siberia - elk 'of monstrious size' (Frazier), reindeer, wild horses, bears, foxes, hares, wolves 'ravenous and merciless' (Lilwall), cranes, geese, ducks, and others. The permafrost, the most frequently mentioned phenomenon, covers the entire territory of the tundra and most of the taiga. The authors mention richness in natural resources as 'a land of diamond and gold' (Thubron). 
Siberia is presented to foreign travelers as a place of cohabitation of the Russian people and the indigenous peoples. Moreover, the authors clearly define the difference between the representatives of these peoples. Most often the travelers notice the human impact on the pristine nature of Siberia, describing it negatively 'human-made chaos' (Frazier). Colin Thubron capaciously, but briefly describes the situation: 'Siberia's essence was wilderness, I thought idly, and human witness destroyed it. <..> They had lost their wild beauty'. Siberia is presented as a unique locus where the earth pressing issues of everyday survival harmoniously coexist with the high importance of the spiritual world and practices. All this contributed to the formation of a unique way of life, special socio-psychological personality traits of the inhabitants of the North.
The historical facts of Siberia, mentioned in the study materials, are exiles, Gulag, communism. For centuries Siberia had been serving as a prison for Russia, a site of forced exile. In the contradiction with wide-open spaces and tragic historical background, Siberia is pictured both as a place of oppression and a place of freedom.

We still have a plenty of concepts to study in the travel writings. They reveal Siberia and infatuate with everything about the Russian North, good and bad: vodka as means of impediment to socializing, beauty of Siberian women, cursing tough Siberian men, mosquitoes and many more. However, Siberia's richness and beauty in metaphor is enough to sustain these wonderful travel writings.

\section{References}

Barhudarov, L.S. (1975). Yazyik i perevod: voprosyi obschey i chastnoy teorii perevoda [Language and translation: The problems of general and special translation theory]. Moscow, Mezhdunarodnyie otnosheniya $[$.

Frazier, Ian. (2010). Travels in Siberia. Picador, New York, 544 p.

Karasik, V.I. (2005). Kontseptyi-regulyativyi [Concepts-the regulators], In Yazyik, soznanie, kommunikatsiya [Language, consciousness, communication], otv. red. V.V. Krasnyih, A.I. Izotov. Moscow, pp. 95-108.

Kondakov, N.I. (1975). Logicheskiy slovar-spravochnik [Logical dictionary-reference book]. Moscow, Nauka, 717 p.

Kubryakova, E.S., Demyankov, V.Z., Pankral, Yu.G., Luzina, L.G. (1996). Kratkiy slovar kognitivnyih terminov [Brief dictionary of cognitive terms]. Moscow.

Lihachev, D.S. (1993). Kontseptosfera russkogo yazyika [The conceptosphere of the Russian language], In Izvestiya AN SSSR. Ser.: Lit. i yaz., 52(1), 3-9.

Lilwall, R. (2009). Cycling Home from Siberia. Hodder \& Stoughton Ltd., Great Britain, 349 p.

Maslova, V.A. (2005). Kognitivnaya lingvistika [Cognitive linguistics]. Minsk, 256 p.

Mowat, F. (1990). Sibir. My Discovery of Siberia. McClelland\&Stewart Inc. Canada, 338 p.

Philosophical Dictionary. (1991). Ed. by Frolov, I, 506 p.

Philosophical Dictionary. (1963). Ed. by M.M.Rosenthal, L.F.Yudin, Moscow, Publishing House of politi. Literature, $544 \mathrm{p}$.

Soviet encyclopaedic dictionary (1982). Moscow, Soviet encyclopedia, 1600.

Stanford, D. (1963). Sun and Snow. The Odyssey of a British girl in Siberia before Revolution. Longmans, Great Britain

$$
-557-
$$


Thubron, C. (2000). In Siberia. London, Penguin Books, 304 p.

Zgazinskaya, O.G. (2008). Kontseptyi Parizh i Kimmeriya v tvorchestve M.A. Voloshina [Concepts Paris and Cimmeria in the works,] avtoref. dis. ... kand. filol. nauk, Arhangelsk.

\title{
Концептуализация образа Сибири \\ в английской языковой картине мира \\ (на материале современных произведений литературы путешествия)
}

\author{
Л.П. Большакова \\ Северо-Восточный федеральный университет \\ им. М.К. Аммосова \\ Россия, 677000, Якутск, ул. Белинского, 58
}

\begin{abstract}
Статья посвящена изучению концептуализации Сибири в английской языковой картине мира. Объектами исследования выступают средства языковой репрезентации, обеспечивающие кониептуализацию образа Севера России. Материалами исследования являются работь современных зарубежных писателей-путешественников, написавших свои труды после долгого пребывания или путешествия по Сибири. На материале их произведений проводится анализ восприятия образов, связанных с Севером, Сибирью. Образ формируется в языковом мире путешественника в результате анализа лексических единии, их значений и ассоииаций, возникающих в сознании языковой личности. В ходе работы были выявлены концептуальные признаки Сибири через выявление ключевых слов-репрезентантов путем сплошной выборки, а также подобран набор категорий в ходе анализа значения языковых единии, репрезентирующих концепт “Сибирь”. В результате анализа образа Сибири через кониепты, созданные в современной английской языковой картине мира, выявлено, что Север для иностраниев ассоииируется не только со специфическими климатическими условиями, географической удаленностью и труднодоступностью, но также и с богатой, но трагической историей земли, с красотой северной природы, искренностью и добродушием жителей, необычным укладом их жизни и с суровыми условиями проживания. Всё это обусловило формирование образа Сибири как чуждой/отличной ото всех страны, как метафору холода и удаленности, воплощенной в оксюмороне угнетения и свободы.
\end{abstract}

Ключевые слова: конщептуализация, Сибирь, образ, современная литература путешествия, английская языковая картина мира.

Научная специальность: 10.00.00 - филологические науки. 